\title{
Pengaruh Media Animasi Berkarakter Islami Terhadap Hasil Belajar Pengetahuan Bumi dan Antariksa
}

\author{
Fauzan Sulman ${ }^{1 *}$, Tanti $^{2}$, Mhmd. Habibi ${ }^{3}$, Aminah ZB ${ }^{4}$ \\ ${ }^{1,2}$ (Tadris Fisika, Universitas Islam Negeri Sulthan Thaha Saifuddin Jambi, Jambi) \\ ${ }^{3}$ (Tadris Matematika, Institut Agama Islam Negeri Kerinci, Jambi) \\ ${ }^{4}$ (Tadris Biologi, Universitas Islam Negeri Sulthan Thaha Saifuddin Jambi, Jambi). \\ * fauzan sulman. E-mail: ${ }^{1}$ fauzansulman@uinjambi.ac.id
}

Receive: 15/01/2021

Accepted: 28/02/2021

Published: 04/03/2021

\begin{abstract}
Abstrak. Penelitian ini bertujuan untuk mengetahui pengaruh media animasi berkarakter islami terhadap hasil belajar mahasiswa pada mata kuliah IImu pengetahuan bumi dan antariksa. Jenis penelitian ini menggunakan pendekatan kuantitatif dengan metode quasi experimental dengan desain penelitian ini adalah the posstest only design with nonequivalent group. Populasi penelitian ini adalah seluruh mahasiswa semester $V$ Tadris Fisika UIN Sulthan Thaha Saifuddin Jambi. Sampel diambil dengan teknik sampling jenuh, dikarenakan semester $\mathrm{V}$ hanya berjumlah berjumlah dua kelas. Instrumen yang dipakai dalam penelitian ini berupa tes soal objektif. Analisi data menggunakan teknik uji ttest. Dari hasil perhitungan diperoleh nilai $-t_{\text {tabel }} \leq t_{\text {hitung }} \leq+t_{\text {tabel }}$ yaitu $2,10 \leq 6,87 \geq+2,10$, maka HO ditolak dan $\mathrm{Ha}$ diterima dengan taraf signifikansi $\alpha=0,05$, maka dapat dinyatkan terdapat pengaruh yang lebih baik hasil belajar mahasiswa menggunakan media animasi berkarakter islami dibanding dengan media animasi tanpa karakter islami. Hasil penelitian dilanjutkan uji koreslasi (Uji phi $(\Phi)$ ), dimana dari hasil perhitungan diperoleh nilai $r_{\text {tabel }} \leq r_{\text {hitung }}$ dengan taraf signifikansi $\alpha=0,05$ yaitu $0,304 \leq 0,0,782$ maka $\mathrm{HO}$ ditolak dan Ha diterima, maka dapat disimpulkan bahwa media animasi berkarakter islami memberikan pengaruh yang signifikan terhadap hasi belajar mahasiswa.
\end{abstract}

Kata kunci: Media Animasi Berkarakter Islami, Pengetahuan Bumi dan Antariksa, Hasil Belajar

\section{Pendahuluan}

Bagian Didalam Al-Qura (kitab suci umat muslim) kriteria generasi terbaik telah jelas di cirikan dalam AIQur'an bahwa manusia yang bertakwa adalah sebaikbaiknya manusia, berilmu tinggi dan berbudi mulia. Proses pendidikan yang berkarakter islami akan menjaga manusia untuk memahami esensi dari kehidupan yang baik (Keshavarz, 2012). Islam tidaklah pernah membatasi pemahaman manusia mengenai sains, dalam surat Ali Imron ayat 190 dijelaskan bahwa memperhatikan kejadian alam, ini merupakan kajian sains dan merupakan tanda bagi orang-orang yang berakal, hal ini mejelaskan bahwa islam tidak hanya menuntut kajian di bidang agama saja dan begitu pula sebaliknya. Islam telah mengajarkan bahwa nilai-nilai samawi dapat digunakan untuk meraih meraih materi yang bersifat duniawi (Shihab, 2002). Perubahan dan 
perkembangan global yang memberikan tantangan tersendiri kepada pendidik (Avidov-Ungar \& Forkosh-Baruch, 2018; Nykvist \& Mukherjee, 2016), sehingga dosen harus dapat memanfaatkan media digital dengan baik salah satunya membuat media animasi dengan berbagai karakter salah satunya berkarakter islami (Sarsengeldin et al., 2013).

Pembelajaran yang berkarakter islami dapat dilaksanakan di semua materi kajian sains salah satunya adalah pada mata kuliah ilmu pengetahuan bumi dan antariksa, dimana banyak berhubungan dengan kejadian dan fenomena alam yang banyak disampaikan di dalam AlQuran sehingga akan menumbuhkan kemampuan berfikir kritis dan kreatif mahsiswa, dimana kemampuan berpikir kreatif sangatlah ditekankan untuk dimilik oleh mahasiswa (Wahyuni and Kurniawan, 2018). Pendidik Apabila kita tinjau sudut pandang proses merdeka belajar sangat menunut aspek berpikir kritis (Saputra et al., 2020). Oleh karenanya didalam pendidikan, dosen harus mampu menjangkau segala ranah ataupu aspek-aspek yang penting dalam proses pembelajaran salah satunya yakni bagaimana melihat sebuah konstruksi yang tepat dalam mengelola proses pembelajaran yang berkulitas antaralain bagaimana menyampaiakan media ajar kepada mahasiswa sehingga menarik dan mudah dipahami.

Pendidik harus memiliki kopentensi pedagogik yang baik sehingga dapat memberikan kenyamanan belajar (Sulisworo \& Toifur, 2016). Hal inilah yang mejadikan peran penting dari sebuah media pembelajaran, salah satunya media animasi. Media animasi dapat menjadi solusi dalam pemberian materi yang tersusun dengan efektifitas tinggi yang membuat mahasiswa berminat terhadap objek materi yang disampaikan. Banyak penelitian telah mebuktikan animasi yang relevan berdampak positif dalam mendukung hasil belajar (Sanchez \& Weber, 2019). Sehingga hasil belajar dapat maksimal.

Media animasi merupakan sarana pembelajaran yang mampu mendukung penyampaian materi yang disampaikan dan mampu meningkatakan minat hasil belajar mahasiswa dalam perkuliahan. Media animasi yang tepat dapat menjadi pembawa materi yang tepat dan efektif dalam memberikan materi pelajaran (Dajani \& Abu Hegleh, 2019) dan dapat menjadikan perhatian mahasiswa dalam proses pembelajaran semakin tinggi sehingga akan membangkitkan motivasi dalam mempelajarinya. Dengan timbulnya motivasi belajar dapat manjadikan peningkatan kualitas belajar mahasiswa sehingga hasil belajar akan maksimal (Sulman, 2019) sesuai dengan hal tersebut (Anggraini. N, Suana. W, 2018) apabila motivasi tinggi maka kemampuan menyelsaikan masalah juga akan menjadi tinggi. Sehingga tujuan pembelajaran dapat dengan mudah tercapai.

Peningkatan antusias dan minat mahasiswa dalam mengkaji materi pengetahuan bumi dan antariksa sudah dapat dicapai dengan baik dengan menggunakan media animasi, lalu ada nilai yang juga tetap harus dijaga yakni nilai agamis, dimana mahasiswa tidak hanya dituntut untuk dapat memahami materi ajar tetapi juga memili akhlak yang mulia, disinilah peran karakter islami harus ditanamkan dalam diri mahasiswa sehingga mahasiswa tidak melupakan jati dirinya sebgai makhluk ciptaan Allah swt. Sejalan dengan hal tersebut (Yasri, 2013) menyatakan bahwa karakter islami bisa dilakukan dengan meberikan Ayat-Ayat AlQur'an atau Hadits didalam materi yang disampaikan bisa dalam aplikasi maupun ilustrasi visual didalam pelaksanaan pembelajaran sehingga menghasilkan perilaku yang baik (Abdussakir, 2007). 
Poses pelaksanaan perkuliahan di atas mengidentifikasikan bahwa media animasi berkarakter islami sangat penting untuk diterapkan, bukan saja dapat memperbaiki hasil belajar materi perkuliahan tetapi lebih penting dari itu yakni dapat memberikan motivasi yang lebih dalam menumbuhkan minat belajar siswa menjadi lebih baik dan mampu memproteksi mahasiswa untuk menjadi individu yang berakhlak mulia. Berdasarkan diurain di atas, diketahui bahwa pentingnya menerapkan media animasi baik dijenjang sekolah dan perguruan tinggi namun belum banyak penelitian yang menerapkan media animasi berkarakter islami pada pada perguruan tinggi, dan belum ada yang menerapkan pada mata kuliah bumi dan antariksa, maka hal tersebutlah yang menjadi dasar peneliti melakukan penelitian yaitu penerapkan media pembelajaran animasi berkarakter islami untuk melihat pengaruhnya terhadap hasil belajar mahasiswa.

\section{Metode}

\section{Desain Penelitian}

Penelitian ini menggunakan pendekatan kuantitatif dengan metode quasi experimental dengan desain pada penelitin ini adalah the posttest only design with nonequivalent group. melibatkan dua kelompok, (Sugiyono, 2014) yaitu satu kelas eksperimen dan kelas dijadikan sebagai kelas kontrol, Adapun desain dari penelitian dapat dilihat pada Gambar 1.

\begin{tabular}{|c|c|}
\hline$X$ & $\begin{array}{l}\mathrm{O}_{1} \\
\mathrm{O}_{2}\end{array}$ \\
\hline
\end{tabular}

Gambar 1. Desain Penelitian The Posttest Only Design With Nonequivalent Group

Perlakuan (X) hanya dilakukan pada kelas eksperimen (O1) dengan menerapkan media animasi berkarakter islami sedangkan pada kelas kontrol (O2) tidak diberikan, letak perbedaan yang mendasar adalah tidak adanya treatmmen karakter islami di kelas kontrol, dengan prinsip penelitian untuk sebisa mungkin memberikan kemiripan langkah langkah dalam penelitian, sehingga perbedaan kedua variabel tidak mencolok secara signifikan. Adapun langkah-langkah penelitian yang dilakukan dapat dilihat pada Gambar 2.

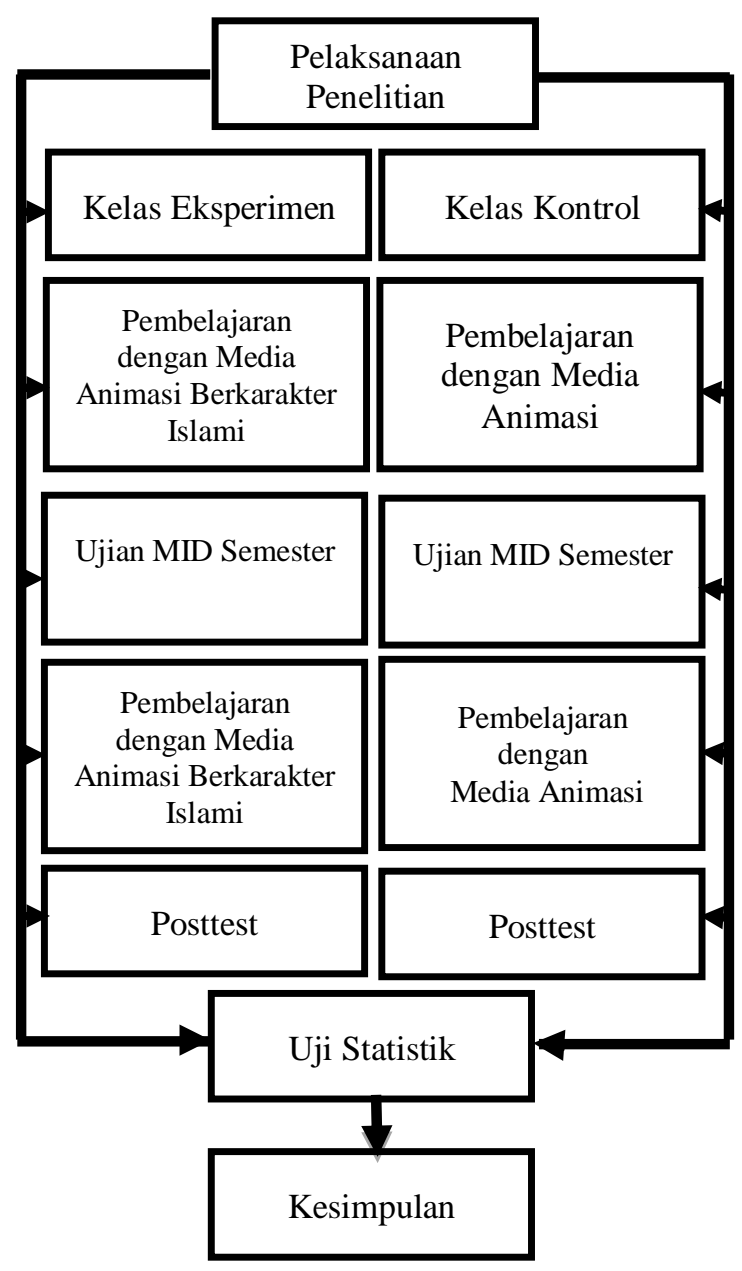

Gambar 2. Bagan Pelaksanaan Penelitian

\section{Subjek Penelitian}

Populasi penelitian ini pada semester ganjil tahun akademik 2019/2020 yaitu tepatnya mahasiswa semester V UIN Sulthan Thaha Saifuddin Jambi yang berjumlah dua kelas. Penentuan sampel pada penelitian berupaya untuk dapat 


\section{(Fauzan Sulman,Tanti, Mhmd. Habibi, Aminah ZB)}

mempertahankan keakuratan sumber penelitian (Sugiyono, 2014) yakni dengan teknik sampel jenuh. Teknik pengambilan sampel jenuh yakni dengan menjadikan seluruh popolusi sebagai subjek penelitian (Sugiyono, 2014). Adapun jumlah mahasiswa yang dilibatkan dalam penelitian ini sebanyak 42 Orang mahasiswa, dimana 23 Orang ditetapkan sebagai kelas eksperimen yakni semester $\mathrm{V}$ kelas $B$, dan semester $V$ kelas $A$ dijadikan kelas kontrol dengan jumlah mahasiswa sebayak 19 Orang.

\section{Instrumen Penelitian}

Peneitian merupakan sebuah kegiatan yang pada dasarnya betujuan untuk melakukan sebuah pengukuran (Sugiyono, 2014) dari sebuah langkah ilmiah, sehingga dibutuhkan alat bantu yang tidak hanya baru tetapi juga akurat dalam melakukan sebuah penelitian, dengan kata lain disebut dengan instrumen. Penelitian ini menggunakan dua macam instrumen perangkat pelaksanaan proses perkuliahan yakni rencana pelaksanaan perkulihan dan instrument penilaian hasil belajar yakni intrumen tes akhir penilaian (posttes). Instrument rancangan pelaksanaan pembelajaran dilakukan validitas logis yakni meminta ke ahli dibidangnya (Supardi, 2015: 125) yakni terdir dari 4 Orang sedangkan Instrumen tes berupa soal pilihan ganda selain dilakukan validitas logis pada ahli juga akan dilakukan analisis kalibrasi dengan 4 kriteria dasar untuk menunjukkan sebuah kelayakan sebuah instrument yakni harus valid, reliabilitasnya harus tinggi, tingkat kesukaran dan daya pembeda harus dalam kategori sedang. Hal tersebutlah yang mejadi dasar harusnya dilakukan analisis perhitungan sebagai pemenuhan instrument yang benar-benar berkualitas.

Hasil validitas logis untuk rencana pelaksanaan pembelajaran didapatkan kesimpulan dengan meminta pertimbangan pendapat-pendapat para ahli (Supardi, 2015:123) didapat kesimpulan bahwa instrument RPS valid dan dapat digunakan pada mata kuliah bumi dan antariksa, sedangkan untuk instrument tes hasil belajar dapat disimpulkan untuk validitas logisnya soal layak dan bisa digunakan pada matakuliah bumi dan antariksa dan dilanjutkan dengan analisi isi instrument didapatkan bahwa instrument soal tes pilihan ganda tersebut valid untuk digunakan dan ditinjau dari analisis Indeks kesukaran soal dan daya beda soal instrument tersebut memilik kategori nilai sedang dengan kata lain soal terebut dapat digunakan baik untuk mahasiswa berkemampuan tinggi maupun rendah, kemudian ditinjau dari uji reliabilitasnya memiliki nilai koefisien sebesar 0,782 dengan kata lain memiliki reliabiliasnya sangat tinggi sehingga dapat menjadi bisa dismpulkan dapat menjadi instrument baik terhadap perubahan kondisi dilapang yang bisa saja mengalami perubahan, dengan kata lain hasil belajar mahasiswa dengan instrument tersebut sangat tepat untuk dapat digunakan

\section{Teknik Analisis Data}

Teknik yang digunakan dalam analisis data untuk melihat bagaimana pengaruh media animasi berkarakter islami terhadap hasil belajar mahasiswa mengunakan 2 jenis metode yaitu metode uji $t$ dan metode uji korelasi phi. Adapun tujuan dilakukan uji $t$ yakni untuk melihat bagaimanakah perbandingan dua variabel apakah terdapat kesamaan atau perbedan dalam mempengaruhi hasil belajar mahasiswa, lebih dalam lagi uji perbandingan tersebut dapat melihat pengaruhnya baik berupa keadaan dari dua buah variabel yang dianalisis (Riduawan, 2018), sedangkan untuk metode kedua yakni teknik korelasi phi dimaksudkkan 
karena variabel benar-benar dipisahkan secara taja (Sudijono, 2019), sehingga kita bisa mengetahui besarnya signifikansi pengaruh media animasi berkarakter islami dalam mempengaruhi hasil belajar mahasiswa.

Analisis penelitian didahului uji prasyarat karena bermanfaat untuk melihat ketepatan sebuah instrument yang diambil, dimana bentuk uji prasyarat yang digunakan yakni uji normalitas dan homogenitas. Adapun Uji homogenitas menggunakan uji chi kuadrat $X^{2}$ (Riduwan, 2018: 187), digunakan dalam membuktikan bagaimanakah bentuk distribusi sebuah sampel tersebut, apakah berdistribusi normal atau tidak sedangkan Uji $F$ digunkan melihat bagai varians kelompok sampel pada kedu kelas yang dipisahkan apakah homogen atau tidak. Setelah uji prasyarat dilakukan dan ternyata normal dan homogen barulah uji t dan korelasi phi dapat dialaksanakan untuk melihat perbedaan pengaruh dan signifikansi pengaruhnya tehadap hasil belajar ilmu pengetahuan bumi dan antariksa.

\section{Hasil dan Pembahasan}

\section{Hasil Temuan Terkait Hasil Belajar}

Data hasil temuan penilaian didapatkan dari tes akhir (posttes) dengan jenis soal yang digunakan adalah pilihan ganda, nilai hasil belajar mahasisw yang dilihat adalah pada aspek kognitif, seperti terlihat pada Tabel 1

\begin{tabular}{clcc}
\hline No & Parameter & $\begin{array}{c}\text { Kelas } \\
\text { Eksperimen }\end{array}$ & $\begin{array}{c}\text { Kelas } \\
\text { Kontrol }\end{array}$ \\
\cline { 3 - 4 } Posttest & Posttest \\
\hline 1 & $\begin{array}{l}\text { Jumlah } \\
\text { mahasiswa }\end{array}$ & 23 & 19 \\
\hline 2 & Nilai teredah & 69,1 & 56,50 \\
\hline 3 & $\begin{array}{l}\text { Nilai } \\
\text { tertinggi }\end{array}$ & 93,75 & 86,85 \\
\hline 4 & $\begin{array}{l}\text { Rata-rata } \\
\text { nilai }\end{array}$ & 78,46 & 75,89 \\
\hline
\end{tabular}

Tabel 1. Nilai Posttes Hasil belajar
Berdasarkan data tersebut dapat dinyatakan bahwa nilai rata-rata pada kelas ekperimen lebih baik dibandingkan kelas kontrol, baik ditnjau dari skor nilai tertinggi maupun terendah, kelas ekperimen tetap memiliki nilai yang lebih baik dibandingkan dengan kelas kontrol. Data kuantitatif yang didapatkan perlu dilakukukan uji prasyrat untuk menjawab hipotesis penelitian yang diajukan yakni apakah terdapat pengaruh media animasi berkarakter islami terhadap hasil belajar mahasiswa dan bagaimanakah signifikansi pengaruhnya terhadap hasil belajar mahsiswa, untuk menjawab hal tersebut di atas terlebih dahulu harus melakukan sebuah uji prasyarat, sehingga analisinya tepat dan akurat sebelum dapat digunakan.

Uji Prasyarat baik uji normalitas maupun uji homogenitas dilakukan dengan menggunakan data tes akhir (Ujian akhir Semester) mahasiswa pada mata kuliah bumi dan antarikasa. Uji nomalitas pada kelas ekperimen dengan nilai $\alpha=0,05$ atau $5 \%$ didapatkan hasil $X^{2}$ hitung $\leq X^{2}{ }_{\text {tabel, }} 3,328 \leq$ 11,070 maka data kelas ekperimen berdistribusi normal sedangkan kelas kontrol $X^{2}$ hitung $\leq X^{2}$ tabel, $6,382 \leq 11,070$ dapat dinyatakan data juga berdistribusi normal. Uji Homogenitas menggunakan taraf signifikan $\alpha=5 \%$ maka diperoleh nilai $X^{2}{ }_{\text {tabel }}=2,10$ dan $X^{2}$ hitung $=1,37$. Jadi $X^{2}$ hitung $\leq X^{2}$ tabel dapat disimpulkan varian-varian datanya homogen

Setalah uji prasyrat dilakukan, dilanjutkan dengan uji t untuk menganalisis perbedaan hasil belajr mahasiswa yang dianalilis bedasarkan niali tes akhir mahasiswa. Seperti tabel 2.

\begin{tabular}{|c|c|c|c|c|}
\hline \multirow[b]{2}{*}{ No } & \multicolumn{2}{|c|}{ Nilai Uji t } & \multirow{2}{*}{$\begin{array}{l}\text { Perbandingan } \\
\text { Nilai Uji } \mathrm{t} \\
-\mathrm{t}_{\text {tabel }} \leq \mathrm{t}_{\text {hitung }} \\
\leq+\mathrm{t}_{\text {tabel }}\end{array}$} & \multirow[b]{2}{*}{ Kesimpulan } \\
\hline & $t_{\text {hitung }}$ & $\mathrm{t}_{\text {tabel }}$ & & \\
\hline 1. & 6,87 & 2,10 & $\begin{array}{l}2,10 \leq 6,87 \geq \\
+2,10\end{array}$ & $\begin{array}{l}\mathbf{H}_{o} \text { ditolak } \\
\text { dan } \mathbf{H}_{\mathrm{a}} \\
\text { diterima }\end{array}$ \\
\hline
\end{tabular}

Tabel 2. Uji perbedaan hasil belajar (Uji t) 
Berdasarkan hasil analisis dengan df sebesar 42 maka diperoleh nilai ttabel pada taraf signifikan $5 \%=2,10$. Sedangkan nilai thitung $=6,87$. Dengan demikian $\mathrm{Ha}$ diterima dan Ho ditolak yang berarti antara kedua variable memiliki perbedaan. Kesimpulan yang dapat dinyatakan adalah terdapat perbedaan media animasi berkarakter islami terhadap hasil belajar mahasiswa. Hasil tersebut sebenarnya telah menunjukkan bahwa pembelajaran dengan media animasi berkarakter islami telah memberikan pengaruh yang lebih baik dibandingkan dengan anamasi tanpa berkarakter islami, Kemudian anilis penelitian di lanjutkan peneliti untuk melihat seberapa bersarkah signifikansi pengaruh media animasi berkarakter islami tersebut terhadap hasil belajar mahasiswa pada mata kuliah ilmu pengetahuan bumi dan antariksa, maka peneliti melanjutkan analisis dengan uji korelasi phi dengan nilai yang dapatkan seperti Table 3.

\begin{tabular}{|l|l|l|l|l|}
\hline $\mathrm{N}$ & \multicolumn{2}{|l|}{ Nilai Uji $\Phi$} & Perbandingan & Kesimpulan \\
\cline { 2 - 3 } $\mathrm{o}$ & $\mathrm{r}_{\text {hitung }}$ & $\mathrm{r}_{\text {tabel }}$ & $r_{\text {tabel }} \leq r_{\text {hitung }}$ & Kitolak \\
\hline 1. & 0,78 & 0,30 & $0,304 \leq 0,782$ & $\begin{array}{l}\mathbf{H}_{\mathbf{o}} \text { dan } \mathbf{H}_{\mathbf{a}} \\
\text { diterima }\end{array}$ \\
\hline
\end{tabular}

Tabel 3. Uji Korlasi (Uji phi (Ф))

Berdasarkan hasil perhitungan Analisis nilai korelasi phi $=0,782$ adalah lebih besar dibandingkan rtabel yang didapatkan pada taraf signifikansi 0,05 atau $5 \%$ yaitu sebesar 0,304 . Maka $r_{\text {tabel }} \leq r_{\text {hitung }}$ atau $0,304 \leq 0,782$. Dengan demikian, berarti media animasi berkarakter islami memiliki dampak yang signifikan dalam mempengaruhi hasil belajar mahasiswa pada mata kuliah bumi dan antariksa.

\section{Disikusi}

Penelitian ini bertujuan mencari tahu bagaimankah pengaruh media animasi berkarakter islami terhadap hasil belar mahasiswa pada mata kuliah ilmu pengetahuan bumi dan antariksa, dan lebih dalam lagi ingin melihat bagai manakah signifikasi pengaruh media animasi berkarakter islami tersebut dalam mempengaruhi hasil belajar mahasiswa. Pelaksanaan pembelajaran era 4.0 sangat menekankan pada proses pembelajaran yang tidak monoton dan memiliki kreatifitas yang tinggi, dengan kata lain dosen dituntut untu dapat memberikan infomasi kepada mahasiswa dengan cara yang lebih menarik sehingga mahasiswa dapat lebih antusias dalam proses perkuliahan. Dosen dituntut untuk mampu menguasai teknologi salah satunya kreatifitas dunia digital antaralian adalah media animasi, karenanya dosen diharuskan dapat membangun minat dan motivasi belajar mahasiswa.

Hal ini dikarenakan tidak semua mahasiswa memiliki motivasi dan antusiasme yang tinggi dan muncul dari dirinya sendiri dalam proses perkulihan dengan kata lain tidak adanya keingintahuan mahsiswa yang muncul dalam dirinya untuk melakukan aktivitas perkuliahan. Sebagian lagi beranggapan perkuliahan hanyalah sebuah kewajiban untuk medapatkan nilai atau gelar sarjana, hal ini lah yang harus dirubah karena mahasiswa harus memiliki paradigm yang baik, bahwa perkuliahan adalah sebuah jalan untuk mencerdaskan diri dari ke bodohan.

Dalam sebuah lembaga yang didalamnya terdapat proses perkuliahan diperlukannya suatu dorongan dari dalam maupun dari luar diri mahasiswa yang biasa disebut dengan motivasi belajar. Hal ini diarenakan motivasi belajar dapat mendorong orang utuk mencapai hasil belajar yang maksimal, motivasi dapat menjadikan pengerak dalam diri mahsiswa untuk megetahui sesuatu yang baru yang dianggap menarik dan penting untuk dapat diamati, dipelajari dan diaplikasikan, mtovisa dapat menjadi garda terdepan dalam diri individu mahasiswa untuk 
mewujudkan kehidupan yang lebih baik, dan tidak kalah penting minat mahasiswa juga mempunya peranan penting dalam melakukan proses perkuliahan, mahsiswa yang memiliki minat yang tinggi akan lebih cendrung mau menggali lebih jau materi perkuliahan yang disampaikan karenya dibutuhkan karakter media animasi yang tepat untuk dapat menciptkan minat dan motivasi belajar mahasiswa untuk mejadi lebih baik, salah satunya adalah media animasi berkarakter islami.

Media animasi berkarakter islami diyakini dapat menjadi sebuah dasar dan solusi untuk meningkatkan hasil belajarr mahasiswa untuk menjadi lebih sempurna, karena media berkarakter islami akan menjadikan mahasiswa belajar terdorong dalam dirinya tanpa melupakan bahwa jati dirinya adalah makhluk Allah swt, dengan adanya korelasi antara ayat-ayat AIQur'an dengan sains pada materi perkuliahan ilmu pengetahuan bumi dan antariksa yang berkaitan dengan alam, mahasiswa juga akan menjadi semakin berminat dan termotivasi dengan materi yang dipelajari sehingga hasil belajar akan semakin maksimal dan tujuan perkuliahan dapat dengan mudah tercapai.

\section{Pengaruh Penerapan Media Animasi Berkarakter Islami Terhadap Hasil Belajar mahasiswa}

Berdasarkan temuan peneliti di lapangan baik berupa hasil data yang telah dilakuka analisis dapat ditarik sebuah kesimpulan yakni terjadi perbedaaan peningkatan hasil belajar mahasiswa baik kelas eksperimen maupun kelas yang dijadikan kontrol dalam penelitian. Hal ini di sebabkan oleh adanya perbedaan perlakuan (treatmen) yang diberikan, walaupun sebenarnya peneliti berusaha untuk meminimalisir perbedaan yang mencok dalam penelitian ini, perbedaan hanya terletak pada dua kata yakni berkarakter islami. Mahasiswa pada kelas ekperimen yang menerapkan media animasi berkarakter islami cendrung mengalami suasana belajar yang lebih menarik, meningkatkan antusias mereka terhadap sains dan AlQur'an, hal ini dikarenakan banyak materi sains yang disampaikan malah sudah diterangkan jawabannya dalam AlQur'an dan Hadist, hal ini membuat mahasiswa semakin tertarik sehingga memunculkan minat dalam dirinya sendiri untuk memahami materi yang sedang dipelajari. Mereka tidak hanya memperoleh materi dari buku yang cendrung menjenuhkan, akan tetapi pembelajar yang diberikan akan akan memadukan analisis yang biasa didapat dari buku ataupun kajian sains mengenai pengetahuan bumi dan antariksa secara umum dengan AlQur'an dan hadits, sehingga fenomena-fenomena alam yang di bahas akan menjadi lebih menarik.

Pembelajaran dengan menggunakan media animasi berkarakter islami pada mata kuliah ilmu pengetahuan bumi dan antariksa pada kelas eksperimen dan media animasi tanpa karakter islami pada kelas kontrol, dapat ditarik kesimpulan bahwa perbedaan perlakukan (treatmen) yang diberikan hanya berbeda terhadap karakter islami saja selain itu thapan perkuliahan dilakukan sama, tapi efek yang ditimbulkan sungguh luar biasa dimana mahasiswa akan medapatkan perasaan untuk lebih berminat untuk memahami materi ilmu pengetahuan bumi dan antariksa dan menambah keingin tahuan tarhadap materi yang sedang dipaparkan. Perbedaan sangat terlihat jelas ketika hanya media animasi yang diberikan, ada waktu mahasiswa merasa jenuh untuk mendapat materi tersebut karena dirasakan sudah banyak dijelaskan di dalam buku maupun media online, kurangnya antusias mengakibatkan mahsiswa tidak mau mengemukakan pendapatnya dan ada juga yang takut untuk menjawab karena merasa kesalahan 
menjawab soal akan mengurangi penilaian, dengan kata lain pengetahuan yang dipelajari tidak berdasarkan kebutuhan dan keingitahuan tapi lebih berdasarkan hanya sebuah kewajiban yang harus diselesaikan. Sedangkan pada kelas dengan media animasi yang berkarakter islami hampir sebagian besar mahasiswa berani mengutarakan pemahamannya terhadap materi yang dipelajari dan mahasiswa berani menganalisis lebih jauh materi yang dipelajari dan saat diskusi dilakukan mahasiswa dengan media animasi berkarakter islami lebih terbuka dalam menyampaikan baik pemahan yang dimengerti maupun tidak dimengertinya, dan ditinjau dari tujuan pelaksaanaan perkuliahan yang disusun dapat tercapai dengan baik dan tingkat kepuasan mahasiswa terhadap materi yang diberikan sangat tinggi.

Perbedaan hasil belajar yang terjadi pada kelas kontrol diyakini dikarenakan oleh tidak adanya penanaman karakter secara khusus sehingga, pemamparan materi bergantung hanya pada bentuk media animasi saja. Mahasiswa tekadang cendrung merasa bosan dengan beberapa materi yang dianggap tidak relefan dengan media yang disediakan, walaupun tidak dapat dipungkiri bahwa media animasi yang sebenarnya memiliki kemampuan untuk meningkatkan minat mahasiswa yang baik pada mata kuliah bumi dan antariksa, akan tetapi dalam kondisi tertentu motivasi tidak bisa dimunculkan saat proses perkuliahan berlangsung, kurangnya motivasi dan minat mahasiswa tentang pentingnya materi bumi dan antariksa tersebut sehingga terjadi kejenuhan pada mahasiswa untuk lebih mendalami materi yang disampaikan. Mahasiswa cendrung untuk pasif dan jenuh saat animasi yang diberikan tidak sesuai dengan harapan mahasiswa, dan juga mahasiswa merasa bosan dengan materi yang diampaikan pada media animasi, yang materinya hampir sama dengan buku-buku yang mereka gunakan. Pada kelas kontrol disaat media animasinya tidak berkarakter islami pada pelaksanaan perkuliahan ada beberapa materi yang disampaikan hampir tidak berpengaruh pada motivasi dan minat mahasiswa sehingga solusi yang dilakukan dengan berusahan melanjutkan materi ke materi lainnya untuk mempercepat penyampaian perkuliahan dan menyebabkan mahasiswa merasa tidak memiliki kenyamana dalam pembelajaran sehingga keunggulan media animasi menjadi hilang dan dapat berdampak pada tidak maksimalnya proses pembelajaran yang dilakukan. Oleh karenanya penambahan karakter islami merupakan pelengkap yang sempurna dalam proses perkuliahan ilmu pengetahuan bumi dan antariksa.

Temuan yang peneliti temukan dilapangan sesuai dengan pendapat (Sanchez and Weber, 2019) banyak penelitian yang menyatakan media animasi dapat meningkatkan hasil belajar, sejalan dengan itu (Dajani and Abu Hegleh, 2019) menjelaskan bahwa animasi yang tepat dapat menjadikan pembelajar yang efektif dan efisien. Hal ini yang menjadikan dasar untuk menambah karekteristik islami pada media animasi, karena media animasi dengan pelengkap yang sempurna dalam perkuliahan ilmu pengetahuan bumi dan antarikasa yakni dengan berkarater islami, dapat menjadi solusi terbia dari yang terbaik selama proses perkuliahan, dimana berkarakter islami yang dimaksudkan disini yakni dengan cara pemberian ayat-ayat AlQu'an dan Hadits kedalam materi perkuliahan (Yasri, 2013), sehingga menghasilkan perilaku yang baik (Abdussakir, 2007) dan mahasiswa menjadi termotivasi dan tumbuh minat yang lebih besar dari dalam diri mahasiswa dalam perkuliahan ilmu pengetahuan bumi dan antariksa sehingga hasil belajar akan menjadi sangat maksimal. 


\section{Signifikansi Pengaruh Media Animasi Terhadap Hasil Belajar}

\begin{abstract}
Berdasarkan temuan peneliti dilapangan ditemukan bahwa media animasi berkarakter islami berpengaruh signifikan terhadap hasil mahasiswa, ini dakerankan media animasi berkarakter islam dapat menjadi sebuah wadah yang sempurna dalam meningkatkan minat dan motivasi belajar mahasiswa. Media animasi telah banyak terbukti dapat memperbaiki kualitas dalam proses belajar(Sanchez and Weber, 2019) sejalan dengan hal tersebut, penelitian (Yuliharti, 2019) mengatakan karakter islami telah terbukti memiliki hasil yang luar biasa dan pencapaiannya telah di akui banyak orang, sehingg jelaslah bahwa media animasi berkarakter islami mampu memaksimalkan segala aspek pada perkuliahan.
\end{abstract}

Peneliti juga melakukan proses wawancara dengan dua belas orang mahasiswa yang diambil dengan memperhatikan nilai tes akhir belajar mahasiswa setelah perkuliahan ilmu pengetahuan bumi dan antariksa dilaksanakan, yakni dengan rincian enam orang mahasiswa di kelas eksperimen dan enam orang mahasiswa lagi dikelas kontrol. Peneliti membagi enam orang mahasiswa di setiap kelas secara seimbang dengan pembagian setiap kelas diwakili oleh dua orang mahasiswa yang bernilai tinggi, dua orang mahasiswa yang bernilai sedang dan dua orang mahasiwa yang bernilai rendah. Hasil wawancara ini hanya dilakukan terkait dengan proses belajar mengajar pada perkuliahan ilmu pengetahuan bumi dan antariksa. Wawancara dilakukan untuk melihat bagaimanakah motivasi dan minat belajar yang dialami mahasiswa selama proses perkuliahan dan apa yang menjadi aspek ketertarikan mahasiswa selama pekuliahan berlangsung. Dari hasil wawancara peneliti untuk kelas eksperimen dimana media animasi yang berkarakter islami dapat menggugah perasaan mahasiswa untuk menjadi lebih baik, menyadari diri dan kualitasnya dan selalu berupaya untuk memperbaiki dan mendalami materi ajar lebih luas lagi, disaat pemberian ayat-ayat AlQur'an mahasiswa termotivasi dan lebih berminat untuk mengkaji materi bumi dan antariksa tersebut, dikarenakan antusias yang sangat tinggi menyebabkan proses perkuliahan dapat berlangsung dengan efektif dan efisien, sedangkan pada kelas kontor mahasiswa menganggap media pembeljaran animasi cukup efektif dalam proses perkuliahan, tetapi bebrapa materi yang dilakukan dirasakan monoton sehingga mahasiswa dalam kondisi tertentu tidak dapat termotivasi dan minat perkuliahannya hanya sebatas kewajiban perkuliahan saja, bukan datang dari keingintahuannya dalam mempelajari materi perkuliahan ilmu pengetahuan bumi dan antariksa.

Penelitian ini juga sejalan dengan hasil penelitian (Sukiyasa and Sukoco, 2013) yang menyampaikan bukti bahwa media animasi yang tepat dapat meningkatkan motivasi belajar. Sejalan dengan itu penelitian (Yuliharti ,2019) hasil belajar akan menjadi luar biasa apabila adanya karakter islami. Hal tersbut dia atas dapat dimaknai bahwa media animasi dengan karakter islami dapat menjadi solusi yang terbaik dalam menciptkan mahasiswa yang terbaik dari yang terbaik dan hasilnya akan bepengaruh signifikan, sesuai dengan hasil penelitian yang didapatkan oleh peneliti bahwa model pembelajaran dengan media animasi berkarakter islami dapat memberikan pengaruh yang signifikan terhadap hasil belajar mahasiswa pada mata kuliah bumi dan antariksa.

Adapun yang menjadi keterbatasan yang peneliti rasakan selama penelitian adalah, bahwa perlu dketahui tidaklah 
semua mahasiswa mampu memahami dengan baik media animasi yang diberikan tanpa penjelasan yang tepat dan akurat, dan terdapat mahasiswa yang tidak mampu memahami keterkaitan antara materi perkuliahan bumi dan antariksa yang disampaikan dengan hubungannya Al'Quran dan Hadits. Hal ini dikarenakan bahwa ada beberapa mahasiswa yang belum pernah untuk mencoba atau melakukan perkuliahan dengan mengaitkan pengetahuan sain dengan Al'quran dan Hadits. Hal lain yang menjadi kendala selama penelitian yakni kurangnya informasi mengenai tafsir dari ayat dan hadits yang disampaikan. dalam hal pemberian contoh contoh materi perkuliahan yang disampaikan juga masih belum banyak contoh yang diberikan didalam media animasi yang berkarakter islami yang saling berkaitan dengan AlQu'an dan Hadits sehingga ada beberapa materi perkuliahan yang tidak dapat dipaparkan dengan jelas. Oleh karenanya peneiliti berharap ada penelitian serupa yang dapat menyempurnakan penelitian ini lebih tepat, baik dari sudut padang keterkaitan antara sains dengan AlQur'an dan hadits dan juga bagaimana penafsiran dari ayat dan hadits yang disampaikan dan juga ditinjau dari sudut pandang asbabul nuzul ayat tersebut dan asbabul wut hadits tersebut, sehingga media animasi yang berkarakter islami yang diberikan kepada mahasiswa selam perkuliahan bumi dan antariksa dapat disampaikan dengan tepat dan akurat dan mahasiswa dapat dengan mudah memahami dan menganalisis materi yang disampaikan.

\section{Simpulan}

Simpulan dapat bersifat generalisasi temuan sesuai permasalahan penelitian, dapat pula berupa rekomendatif untuk langkah selanjutnya Berdasarkan hasil penelitian yang didaptkan peneliti yakni berdasarkan analisis uji $\mathrm{t}$ bahwa terdapat perbedaan hasil belajar mahasiswa yang lebih baik di kelas yang yang diberikan dengan media animasi berkarakter islam dengan tanpa berkarakter islami, dimana dapat dinyakan bahwa media animasi berkarakter islami memberikan pengaruh yang lebih baik, baik dilihat dari sudut pandang penilaian maupun tingkah laku mahasiswa dan ketika dianalisis lebih lanjut dengan uji korelasi phi dapat dismpulkan bahwa pengaruh media animasi berkarekter islami memilki efek yang sangat signifikan dalam mempengaruhi hasil belajar mahasiswa pada mata ilmu kuliah ilmu pengetahuan bumi dan antariksa.

Saran yang ingin peneliti sampaikan bahwa sebagai peneliti yang akan melakukan penelitian yang sama, maka lebih baik memberikan pengetahuan terlebih dahulu tentang perkuliahan yang akan dilaksanakan dan juga lebih menggali lagi kertarkaitan antara sains dengan AlQur'an dan Hadits, baik dari sebab turunya ayat AlQur'an dan hadits tersebut dan tentunya juga tafsir-tafsir mengenai ayat tersebut. Hasil penelitian ini diharapkan dapat menjadikan rujukan bagi peneliti lain dalam melakukan penelitian serupa Agar diperoleh penelitian yang lebih baik. Hal lain juga perlu diketahui, diingat dan diaplikasikan bahwa Al'Quran dan hadits merupakan petunjuk yang langsung datang dari Allah swt, petunjuk untuk semua aspek dan ranah kehidupan, dan itu semua akan tercermin dalam karakter islami, yakni menjadi individu yang cerdas dan berakhlak mulia. Hal inilah yang menjadikan rujukan bahwa tentunya peneliti lainnya nanti juga dapat menerapkan karakter islami bukan hanya pada mata kuliah ilmu pengetahuan bumi dan antariksa dan juga pada media animasi, tetapi menerapkan kepada seluruh aspek kehidupan secara umumnya, dan pada mata kuliah lainnya secara khusus dalam bidang pendidikan. 
Jurnal Edumaspul, 5(1), Year 2021- 145

(Fauzan Sulman,Tanti, Mhmd. Habibi, Aminah ZB)

\section{Daftar Pustaka}

Abdussakir. (2007). Ketika Kyai Mengajar Matematika. UIN-Maliki Press.

Anggraini. N, Suana. W, S. F. (2018). Pengaruh Penerapan Blended Learning Berbasis. Jurnal Fisika Dan Pendidikan Fisika, 3(02), 85-93.

http://jurnalkonstan.ac.id/index.php/jurnal\% OAPENGARUH

Avidov-Ungar, O., \& Forkosh-Baruch, A. (2018). Professional identity of teacher educators in the digital era in light of demands of pedagogical innovation. Teaching and Teacher Education, 73. https://doi.org/10.1016/j.tate.2018.03.017

Dajani, D., \& Abu Hegleh, A. S. (2019). Behavior intention of animation usage among universitystudents. Heliyon, 5(10), e02536.https://doi.org/10.1016/j.heliyon.201 9.e02536

Keshavarz, S. (2012). Philosophy of Education in Exceptional Children According to Islam. Procedia - Social and Behavioral Sciences,46,2917-

2921.https://doi.org/10.1016/j.sbspro.2012 .05 .589

Nykvist, S., \&Mukherjee, M. (2016). Who am I?Developing Pre-service Teacher Identity in a Digital World. Procedia - Social and BehavioralSciences,217.https://doi.org/10. 1016/j.sbspro.2016.02.012

Riduawan. (2018). Dasar-Dasar Statistika. Alfabeta.

Riduwan. (2018). Dasar-Dasar Statistika. Alfabeta.

Sanchez, C. A., \& Weber, K. (2019). Using
Relevant Animations to Counter StereotypeThreat When Learning Science. Journal of Applied Research in Memory andCognition,8(4),463-

470.https://doi.org/10.1016/j.jarmac.2019. 08.003

Saputra, R., Kurniawan, N. A., Aiman, U., Alfaiz, A., \& Sari, D. K. (2020). Urgensi Pendidikan Berpikir Kritis Era Merdeka Belajar Bagi Peserta Didik. Tarbawi: Jurnal Ilmu Pendidikan, 16(01), 111-116. Sarsengeldin, M., Satabaldiyev, A., Meirambek, Z.,\&Guvercin, S. (2013). Interdisciplinary Connections and their Influence on MathematicalEducationof Students. Procedia-Social and Behavioral Sciences, 89,866

871.https://doi.org/10.1016/j.sbspro.2013. 08.946

Shihab, Q. (2002). Tafsir Al-Misbah "Pesan dan Keserasian Al-Qur'an. "Lentera Hati.

Sudijono, A. (2019). Pengantar Statistik Pendidikan. Raja Grafindo Persada.

Sugiyono. (2014). Metode Penelitian Kuntitatif, Kualitatif, dan $R \& D$. Alfabeta.

Sukiyasa, K., \& Sukoco, S. (2013). Pengaruh media animasi terhadap hasil belajar dan motivasi belajar siswa materi sistem kelistrikan otomotif. Jurnal Pendidikan Vokasi,3(1),126-137. https://doi.org/10.21831/jpv.v3i1.1588

Sulisworo, D., \& Toifur, M. (2016). The role of mobile learning on the learning environment shifting at high schoolin Indonesia. International Journal of Mobile Learning and Organisation, 10(3), 159170.https://doi.org/10.1504/IJMLO.2016.0 
Jurnal Edumaspul, 5 (1), Year 2021- 146

(Fauzan Sulman,Tanti, Mhmd. Habibi, Aminah ZB)

77864

Sulman, F. (2019). Application of Cooperative

Problem Posing and Prior Motivation

Towards Students Learning Outcomes. 4(2), 93-96.

Supardi. (2015). Penilaian Autentik. Raja Grafindo Persada.

Wahyuni, A., \& Kurniawan, P. (2018).

Hubungan Kemampuan Berpikir Kreatif Terhadap Hasil Belajar Mahasiswa. Matematika, $\quad$ 17(2), 1-8. https://doi.org/10.29313/jmtm.v17i2.4114

Yasri. (2013). Strategi Pembelajaran Matematika yang Bernuansa Islami. http://bdkpadang.kemenag.go.id

Yuliharti, Y. (2019). Pembentukan Karakter Islami Dalam Hadis Dan Implikasinya Pada Jalur Pendidikan Non Formal.
POTENSIA:Jurnal Kependidikan Islam, 4(2),216.https://doi.org/10.24014/potensia .$v 4 \mathrm{i} 2.5918$

\section{Profil Penulis}

Fauzan Sulman M.Pd, lahir di bangko 14 juli 1987, menempuh jenjang sarjana S1 pendidikan Fisika Universitas Negeri Jambi dan S2 Pendidikan Fisika Universitas Negeri Padang, berkerja sebgai Dosen Tadris Fisika di Universitas Islam Sulthan Thaha Saifuddin Jambi. Bersama denga Ibu $\mathrm{Dr}$ tanti dan Aminah Zb, M.Pd yang juga merupakan dosen Tadris Fisika dan Biologi di UIN STS Jambi dan bapak Dr. mhmd Habibi adalah dosen pendidikan matematika di IAIN Kerinci, demikianlah profil singkat dari kami. Terimakasih 